\title{
Perilaku Memilih Umpan dengan Fagostimulan yang berbeda pada Kecoak Jerman Blattella germanica L. (Dictyoptera: Blattellidae)
}

\author{
Rizky Arjunnajat Aliefia, Trisnowati Budi Ambarningrum, Edi Basuki \\ Fakultas Biologi, Universitas Jenderal Soedirman \\ Jalan dr. Suparno 63 Purwokerto 53122 \\ email: rizarjunnajat@gmail.com
}

Rekam Jejak Artikel:

Diterima : 03/10/2019

Disetujui : 21/11/2020

\begin{abstract}
German cockroach (Blattella germanica L.) is one of the essential residential pest insects because of its role as a disease vector. To reduce its population, it can be used with bait techniques. However, there was a rejection of glucose against German cockroaches against phagostimulant-based commercial bait. Therefore it is necessary to review the phagostimulant as a trick component to minimize failure to control German cockroaches based on appeal using German cockroaches strain VCRU (Vector Control Research Unit). The first step to formulating the bait is to find the phagostimulant most sought by German cockroaches. The ingredients used as fagostimlan are sugar, durian, erythritol, and banana. The purpose of this study was to determine the behavior of choosing German cockroaches against bait with different phagostimulants and the peak of feeding activity in German cockroaches. This study used an experimental method with a Completely Randomized Design (CRD) consisting of 4 treatments giving phagostimulant and repeated four times, divided into four test arenas. The treatment consisted of bait, which each contained sugar, durian, erythritol, and banana as phagostimulants. Observation of behavior using the method of behavior sampling is recorded in continuous recording for 24 hours using a Closed Circuit Television (CCTV) camera. The parameters measured were latency, frequency, duration, and peak feeding activity of German cockroaches. The data were analyzed with ANOVA at $p<0.05$. The results showed that the behavior of selecting cockroaches from the VCRU strain on the bait was not significantly different $(p<0.05)$ and was attracted to all feeds provided. Still, gel bait with sugar phagostimulant was the preferred bait by looking at the three parameters of latency, frequency, and duration. The results of the average latency in the VCRU strain to the durian gel for 17 minutes, the intermediate frequency of most visits to the sugar gel in the VCRU strain by ten times, the most extended average duration of the VCRU strain gel for 1 minute 46 seconds and peak eating activity VCRU strains occur between 17:00 - 20:00 WIB.

Keywords: Blattella germanica, duration, frequency, latency
\end{abstract}

\section{Abstrak}

Kecoak Jerman (Blattella germanica L.) merupakan salah satu serangga hama permukiman yang penting, karena peranannya sebagai vektor penyakit. Untuk mengurangi populasinya, dapat digunakan dengan teknik pengumpanan. Namun belakangan ini muncul perilaku glucose aversion pada kecoak Jerman terhadap umpan komersial berbasis glukosa sebagai fagostimulan. Oleh karena itu perlu dilakukan kaji ulang terhadap fagostimulan sebagai komponen umpan untuk meminimalisir kegagalan pengendalian kecoak Jerman berbasis umpan dengan menggunakan kecoak Jerman jantan strain VCRU (Vector Control Research Unit). Langkah awal untuk membuat formulasi umpan tersebut adalah mencari fagostimulan yang paling disukai oleh kecoak Jerman. Bahan yang digunakan sebagai fagostimulan adalah gula, durian, erythritol, dan pisang. Tujuan penelitian adalah untuk mengetahui perilaku memilih kecoak Jerman terhadap umpan dengan fagostimulan yang berbeda dan puncak aktivitas makan pada kecoak Jerman. Penelitian ini menggunakan metode eksperimental dengan Rancangan Acak Lengkap (RAL) yang terdiri dari 4 perlakuan pemberian fagostimulan dan diulang sebanyak 4 kali yang terbagi menjadi empat arena uji. Perlakuan terdiri dari umpan yang masing-masing mengandung gula, durian, erythritol, dan pisang sebagai fagostimulan. Pengamatan perilaku menggunakan metode behavior sampling yang dicatat secara continuous recording selama 24 jam menggunakan kamera Closed Circuit Television (CCTV). Parameter yang diukur berupa latensi, frekuensi, durasi, dan puncak aktivitas makan dari kecoak Jerman. Data yang diperoleh dianalisis dengan ANOVA pada $\mathrm{p}<0.05$. Hasil penelitian yang diperoleh menunjukkan bahwa perilaku memilih kecoak jantan strain VCRU terhadap umpan tidak berbeda nyata $(p>0.05)$ dan tertarik 
dengan semua umpan yang diberikan, tetapi umpan gel dengan fagostimulan gula merupakan umpan yang lebih disukai dengan melihat ketiga parameter latensi, frekuensi, dan durasi. Hasil rata-rata latensi pada strain VCRU menuju gel durian selama 17 menit, rata-rata frekuensi kunjungan terbanyak ke gel gula pada strain VCRU sebanyak 10 kali, rata-rata durasi terlama pada gel gula strain VCRU selama 1 menit 46 detik dan puncak aktivitas makan strain VCRU terjadi antara pukul $17.00-20.00 \mathrm{WIB}$.

Kata kunci: Blattella germanica, durasi, frekuensi, latensi

\section{PENDAHULUAN}

Kecoak Jerman (Blattella germanica L.) adalah salah satu hama yang dapat berperan sebagai vektor penyakit yang paling umum ditemukan di tempat tinggal manusia di seluruh dunia dan dianggap sebagai pengganggu kesehatan manusia karena berdekatan dengan tempat tinggal manusia dan umumnya berkembang biak dan mencari makan di daerah yang kotor (Hadi \& Sigit, 2006). Kecoak Jerman menyukai lingkungan yang hangat, lembab, terdapat makanan, air, serta tempat persembunyian yang sedikit cahaya (Ratnasari, 2014).

Kecoak Jerman berkembang biak dengan cepat dan oleh karena itu sudah sejak lama dilakukan upaya pengendaliannya dengan berbagai cara seperti secara biologis, mekanis maupun secara kimiawi (Amalia \& Harahap, 2010). Salah satu teknik pengendalian yang disinyalir aman terhadap lingkungan adalah dengan teknik pengumpanan (baiting). Umpan kecoak merupakan kombinasi dari beberapa makanan bernutrisi yang digunakan untuk merangsang kecoak supaya datang dan memakan umpan tersebut (Arifah et al., 2016). Komposisi umpan terdiri atas insektisida, matriks umpan, dan fagostimulan. Umumnya gula digunakan sebagai fagostimulan umpan kecoak.

Teknik pengendalian kecoak berbasis umpan komersial telah digunakan di Amerika Serikat sejak tahun 1980-an. Sementara di Indonesia penggunaan umpan komersial dalam pengendalian kecoak dimulai sekitar tahun 1990an. Namun sepuluh tahun kemudian di beberapa negara bagian Amerika Serikat dilaporkan kegagalan pengendalian kecoak Jerman dengan umpan, karena disinyalir kecoak Jerman telah mengembangkan resistensi perilaku terhadap umpan komersial. Fenomena resistensi perilaku pada kecoak Jerman ini dikenal sebagai bait/glucose aversion yang diketahui pertama kali terjadi di Amerika Serikat sekitar 1990 (Silverman \& Bieman, 1993). Ambarningrum et al. (2019, in press) melaporkan ada empat strain kecoak Jerman dari 21 strain kecoak Jerman asal 12 provinsi di Indonesia yang terdeteksi berpotensi mengembangkan perilaku bait/glucose aversion terhadap umpan komersial berbasis glukosa sebagai fagostimulan. Oleh karena itu perlu dilakukan kaji ulang terhadap fagostimulan sebagai komponen umpan untuk meminimalisir kegagalan pengendalian kecoak Jerman berbasis umpan. Langkah awal untuk membuat formulasi umpan tersebut adalah mencari fagostimulan yang paling disukai oleh kecoak Jerman.

Menurut Chan \& Martinez (2007), pakan alami kecoak dapat berupa buah-buahan, gula (pemanis), dan makanan yang mengandung protein nabati maupun hewani. Penelitian tentang fagostimulan bagi kecoak dan serangga pada umumnya telah dilakukan oleh Ahmad \& Suliyat (2011) dengan menggunakan pisang yang membuat kecoak tertarik karena adanya kandungan fruktosa, sementara itu Wang et al. (2004) dengan menggunakan berbagai jenis jenis gula, salah satunya gula rendah kalori. Penelitian lainnya yang dilakukan oleh Pol et al. (2017) menggunakan minuman beralkohol menunjukkan hasil yang positif terhadap kecoak Jerman. Pada penelitian sebelumnya erythritol digunakan sebagai daya tarik terhadap lalat Drosophila sp. tetapi bersifat 
insektisida bagi ordo Diptera (Tang et al., 2017). Maka dari itu penggunaan gula erythritol yang merupakan gula alkohol rendah kalori, serta durian yang memiliki kandungan gula dan alkohol pada penelitian kali ini dapat diuji untuk menarik perhatian kecoak Jerman.

Pada penelitian ini akan mencari perbandingan umpan dari beberapa jenis fagostimulan berupa gula, durian, erytrhitol, dan pisang yang paling disukai kecoak Jerman. Penelitian kali ini akan menggunakan metode pencuplikan perilaku (behavior sampling), dengan pengamatan dan perekaman perilaku memilih fagostimulan selama 24 jam melalui recording and continuous sampling (Martin \& Bateson, 1993), sehingga selain akan diperoleh informasi tentang perilaku memilih makan pada kecoak juga akan diperoleh informasi puncak akitvitas makan kecoak Jerman untuk mendapatkan metode pengendalian yang efektif dan efisien. Tujuan dari penelitian ini adalah untuk mengetahui perilaku memilih terhadap umpan dengan fagostimulan yang berbeda dan puncak aktivitas makan pada kecoak Jerman. Hasil penelitian ini diharapkan dapat memberikan informasi mengenai fagostimulan yang paling menarik bagi kecoak Jerman dan puncak aktivitas makan pada kecoak Jerman.

\section{MATERI DAN METODE}

\section{Materi, Lokasi, dan Waktu Penelitian}

Alat yang digunakan dalam penelitian ini adalah arena uji berupa kotak plastik berukuran 36 $\mathrm{cm} \times 26 \mathrm{~cm} \times 12 \mathrm{~cm}$, toples plastik $16 \mathrm{~L}$, kain, karet, kamera perekam Closed Circuit Television (CCTV), tempat persembunyian (shelter) berupa kardus dan tempat air minum. Bahan yang digunakan dalam penelitian ini adalah vaseline, minyak, cat food, jelly, gula, durian, pisang, erythritol, kecoak Jerman jantan dewasa strain VCRU (Vector Control Research Unit). Strain
VCRU berasal dari Vector Control Research Unit School of Biological Science University Sains Malaysia, Penang, Malaysia. Strain tersebut mulai dipelihara di laboratorium Entomologi-Parasitologi Fakultas Biologi Unsoed sejak bulan Mei 2018.

Penelitian dilaksanakan di Laboratorium Entomologi-Parasitologi Fakultas Biologi Universitas Jenderal Soedirman, pada bulan Februari sampai Juni 2019. Metode penelitian yang digunakan adalah metode eksperimental menggunakan Rancangan Acak Lengkap (RAL), terdiri dari 4 perlakuan pemberian fagostimulan sebagai umpan dan diulang sebanyak 4 kali yang terbagi menjadi empat arena uji. Perlakuan yang dipakai adalah umpan dengan 4 macam fagostimulan yang diletakkan dalam satu arena uji. Masing-masing arena uji berisi 3 ekor kecoak jantan. Pengamatan perilaku preferensi menggunakan metode behavior sampling melalui perekaman menggunakan kamera Closed Circuit Television (CCTV) dan pencatatan secara terusmenerus (continuous recording) selama 24 jam (Martin \& Bateson, 1986).

Data yang diperoleh dianalisis menggunakan analisis ragam pada $\mathrm{p}<0,05$. Apabila terdapat perbedaan yang nyata antar perlakuan akan diuji lanjut menggunakan uji Duncan. Variabel terdiri atas variabel bebas dan variabel terikat. Variabel bebas yaitu umpan dan variabel terikatnya adalah perilaku preferensi terhadap umpan. Parameter yang diamati meliputi latensi menuju umpan, frekuensi kunjungan ke umpan, durasi berada di umpan, serta puncak aktivitas makan pada kecoak Jerman.

\section{Cara Kerja}

\section{Pemeliharaan kecoak Jerman}

Kecoak dipelihara dan dibiakkan di laboratorium Entomologi-Parasitologi Fakultas Biologi UNSOED sejak bulan Mei 2018, pemeliharaan dilakukan dengan memisahkan 
masing-masing strain ke dalam toples plastik yang ditutup menggunakan kain, pada bagian atas toples diolesi campuran vaseline dan minyak agar kecoak tidak dapat naik. Selama pemeliharaan pengecekan, pengolesan dan pemberian pakan dilakukan setiap 5 hari sekali. Pakan yang diberikan selama pemeliharaan berupa pelet (catfood).

\section{Persiapan umpan}

Umpan dasar yang digunakan berupa gel, berbahan dasar agar-agar (nutrijel) plain yang dimasak menggunakan air. Setelah dimasak agaragar didinginkan sampai temperatur $60^{\circ} \mathrm{C}$ kemudian dicampurkan dengan gula, durian, pisang, dan erytrisol. Bahan-bahan yang telah dicampurkan kemudian dihaluskan menggunakan blender, setelah halus bahan-bahan tersebut dituang pada cup plastik. Bahan yang telah tercampur berupa gel gula, gel pisang, gel durian, dan gel erytrisol siap digunakan.

\section{Pengamatan perilaku preferensi}

Disiapkan arena uji berisi tempat persembunyian dari potongan kardus yang dilipat dan air minum yang diletakkan di tengah arena uji serta kamera perekam CCTV. Sebelum dimasukkan ke dalam arena kecoak uji diberi tanda pada bagian dorsal tubuhnya menggunakan cat akrilik. Kecoak dimasukkan ke dalam arena uji dan diaklimatisasi terlebih dahulu selama 1 jam untuk beradaptasi. Setelah 1 jam aklimatisasi, umpan diletakkan pada ke 4 sudut arena uji. Perekaman dilakukan selama 24 jam, dimulai dari pukul 17.00 WIB sampai dengan pukul 17.00 WIB hari berikutnya. Hasil perekaman diamati pada monitor untuk melihat latensi menuju perilaku, frekuensi kunjungan ke perlakuan, durasi berada di perlakuan, dan puncak aktivitas makan dari kecoak Jerman.

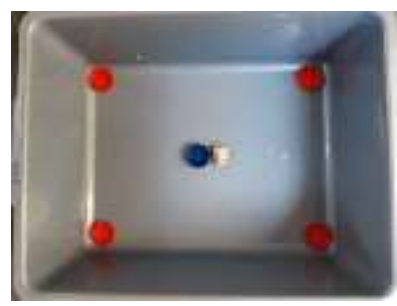

Gambar 1. Skema perlakuan

Data penelitian berupa latensi, frekuensi, durasi, dan puncak aktivitas makan dianalisis dengan Analisis Varian (ANOVA) pada $\mathrm{p}<0,05$, dilanjutkan uji lanjut Duncan Multiple Range Test (DMRT) (Steel \& Torrie, 1995).

\section{HASIL DAN PEMBAHASAN}

\section{Latensi Menuju Umpan}

Hasil penelitian menunjukkan bahwa latensi kecoak menuju umpan tidak signifikan pada taraf $<0,05$. Meskipun tidak ada beda nyata pada latensi menuju umpan, namun terlihat bahwa latensi tercepat menuju ke gel durian dengan rata-rata waktu latensi menuju gel durian selama 1020 detik (Tabel 1). Setiap umpan dikunjungi dalam rentang waktu yang tidak begitu jauh. Kecenderungan mengunjungi masing-masing umpan dikarenakan bahwa setiap umpan dapat menarik perhatian kecoak untuk datang. Hal ini diduga kecoak dalam kondisi kelaparan karena habis dipuasakan, pada kondisi kelaparan kecoak pada umumnya mencari sumber energi praktis yang sangat penting bagi kelangsungan kecoak (Lauprasert et al., 2006).

Tabel 1. Rata-rata latensi kecoak Jerman menuju umpan

\begin{tabular}{|c|c|c|c|c|c|c|}
\hline \multirow[t]{2}{*}{ Strain Kecoak } & \multicolumn{4}{|c|}{ Rata-rata latensi menuju umpan (detik) } & \multirow[b]{2}{*}{ Gel } & \multirow[b]{2}{*}{ Pisang } \\
\hline & Gula & Gel & Durian & Gel Erythritol & & \\
\hline \multirow[t]{2}{*}{ VCRU } & 26 & & 10 & 27 & 19 & 74 \\
\hline & 50 & & 20 & 51 & & \\
\hline
\end{tabular}


Hasil rata-rata latensi kecoak Jerman menuju umpan ditentukan oleh waktu tercepat pergerakan kecoak menuju umpan. Gel durian merupakan umpan pertama yang membuat kecoak tertarik untuk datang, hal ini diduga karena durian memiliki aroma yang paling kuat dibandingkan perlakuan lainnya. Penelitian lain tentang durian digunakan sebagai umpan telah dilakukan Mustikawati et al. (2016), menyatakan aroma durian merupakan umpan yang paling banyak menarik lalat untuk datang karena memiliki aroma yang menyegat. Selain itu durian juga memiliki kadar air pada daging buah sekitar $60 \%$, kadar pati 17,3\%, dan kadar gula mencapai 20,5\% (Antarlina, 2009). Menurut Direktorat Gizi Departemen Kesehatan (1981), durian juga memiliki kadar protein 2,5\%, lemak 3\%, karbohidrat $28 \%$.

Menurut Ahmad et al. (1993), serangga pada umumnya dapat menyeleksi makanannya. Serangga dapat mencari dan mengenali makanan yang sesuai. Ada 3 komponen dasar dari pola perilaku dalam proses makan yang normal, yaitu orientasi makanan, respon menggigit, dan dilanjutkan proses makan (Dethier, 1954). Menurut Waldbauer \& Friedman (1991) saat awal pencarian makannya serangga tertarik terhadap bau makanan yang menarik, namun setelah makanan dikonsumsi dan tidak memenuhi kebutuhan nutrisinya maka serangga akan menghentikan proses makannya dan menari sumber makanan lain yang memenuhi kebutuhan nutrisinya. Aroma yang terdapat pada umpan dapat mempengaruhi datangnya kecoak.

\section{Frekuensi Kunjungan Pada Umpan}

Hasil penelitian menunjukkan bahwa frekuensi kunjungan kecoak pada umpan tidak signifikan pada taraf $<0,05$. Meskipun tidak beda nyata pada frekuensi kunjungan pada umpan, namun frekunsi kunjungan stain VCRU paling banyak adalah ke gel gula, dengan rata-rata frekuensi kunjungan sebanyak 10 kali (Tabel 2). Rata-rata frekuensi kunjungan kecoak dilihat dari seberapa sering kecoak mengunjungi umpan dengan batasan yaitu kecoak sampai berada diatas umpan.

Tabel 2. Rata-rata frekuensi kunjungan kecoak Jerman pada umpan selama 24 jam

\begin{tabular}{ccrrr}
\hline Strain Kecoak & \multicolumn{4}{c}{ Rata-rata frekuensi kunjungan kecoak (kali) } \\
\cline { 2 - 5 } & Gel Gula & Gel Durian & Gel Erythritol & Gel Pisang \\
\hline VCRU & 10 & 8 & 9 & 9
\end{tabular}

Hasil rata-rata frekuensi kunjungan kecoak Jerman pada gel gula merupakan nilai tertinggi dibandingkan dengan umpan lainnya. Hasil ini sesuai dengan penelitian Ahmad (2018), yang menyatakan kecoak jerman tertarik dengan kandungan gula yang tinggi. Kandungan nutrisi pakan menjadi faktor utama dalam kebutuhan pakan hariannya.

Secara umum kecoak Jerman strain VCRU memilih semua umpan untuk dikunjungi. Willis dan Avondet (2005) menjelaskan ketertarikan terhadap aroma umumnya dimiliki oleh tiap jenis serangga. Mekanisme itu membuat serangga melacak bau makanan lalu mengikutinya hingga ke wadah umpan. Perilaku kecoak dalam mendeteksi bau makanan menggunakan kemoreseptor yang terletak pada antenanya, kemudian mendekatinya secara perlahan dan mulai menyentuh makanan tersebut untuk kemudian dikonsumsi.

\section{Durasi Berada Pada Umpan}

Hasil penelitian menunjukkan bahwa frekuensi kunjungan kecoak pada umpan tidak signifikan pada taraf $<0,05$. Meskipun tidak beda nyata pada durasi berada pada umpan, namun strain VCRU lebih menyukai dan paling lama berada pada gel gula, hasil ini dapat dilihat bahwa kecoak 
lebih lama berada pada gel gula dengan rata-rata

105,55 detik (Gambar 1).

durasi waktu dalam pengamatan 24 jam selama

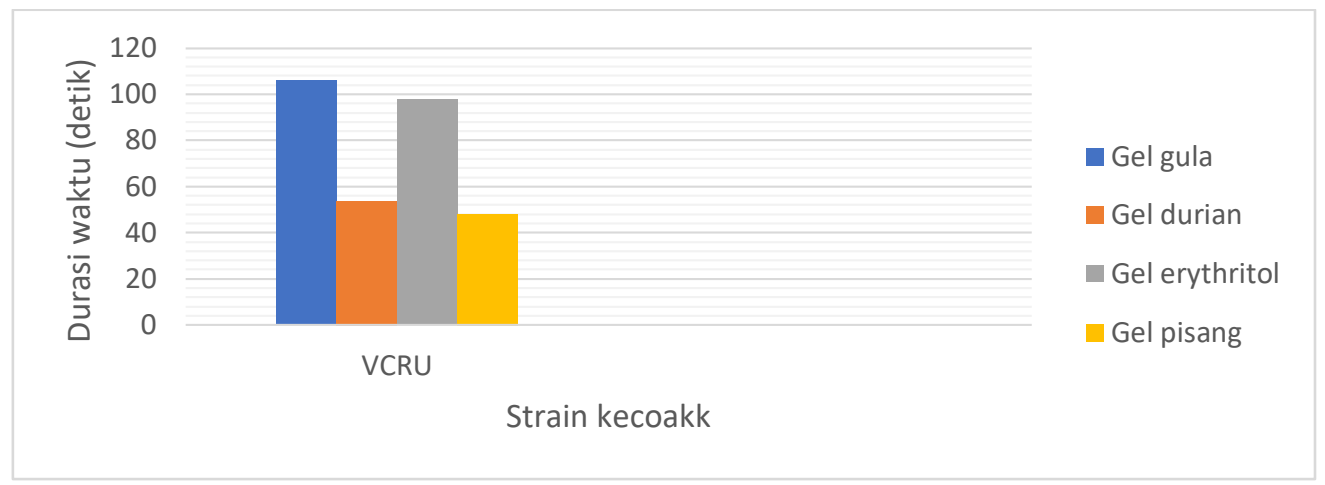

Gambar 1. Rata-rata durasi waktu kecoak Jerman berada pada umpan selama 24 jam

Hasil rata-rata durasi berada pada umpan kecoak Jerman strain VCRU paling lama berada pada gel gula dengan nilai tertinggi, disusul dengan gel erithritol dengan rata-rata durasi tidak begitu jauh. Hasil penelitian didukung oleh pernyataan Winarno (2001), menyatakan bahwa kecoak menyukai makanan yang mengandung gula, protein, dan kadar air tinggi, serta memiliki bau yang menyengat

Pakan yang memiliki aroma kuat lebih menarik perhatian kecoak untuk dikunjungi dan dikonsumsinya. Penelitian sebelumnya yang dilakukan oleh Amalia \& Harahap (2010), kecoak memakan semua media yang digunakan sebagai umpan. Faktor yang mempengaruhi kenapa kecoak tertarik dengan semua kombinasi umpan dikarenakan umpan tersebut memiliki kandungan air, gula, dan protein yang tinggi. Jika kecoak tertarik dan nutrisi dalam umpan sesuai, maka kecoak akan melanjutkan mengonsumsi umpan. Sebaliknya, kecoak akan meninggalkan umpan jika nutrisi dalam umpan tersebut tidak sesuai dengan kebutuhannya (Lauprasert et al., 2006).

\section{Puncak aktivitas makan}

Pada penelitian kali ini selain melihat perilaku memilih umpan pada kecoak, dilakukan juga pengamatan puncak aktivitas makan selama 24 jam untuk mengetahui waktu pergerakan kecoak dalam mencari makan. Berdasarkan hasil yang diperoleh strain VCRU mengalami puncak aktivitas makan antara pukul 17.00 - 20.00 dengan rata-rata aktivitas 33,5 kali kunjungan ke umpan (Gambar 2).

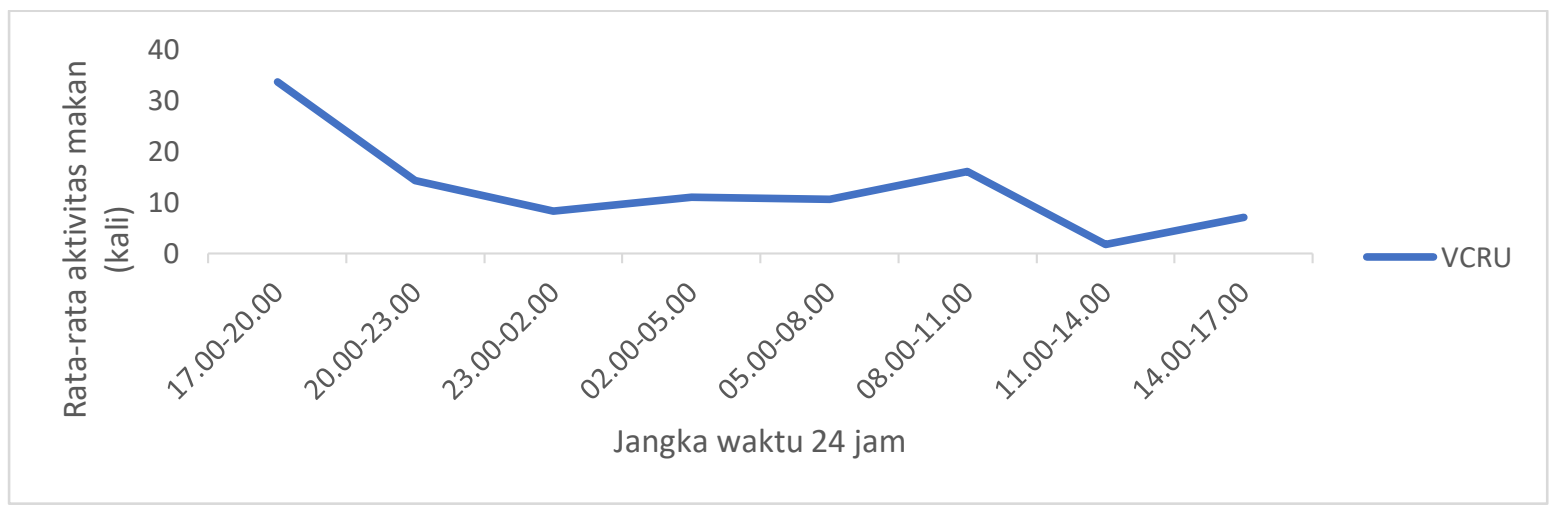

Gambar 2. Rata-rata aktivitas makan kecoak Jerman 
Berdasarkan pengamatan dalam waktu 24 jam strain VCRU mengalami fluktuasi aktivitas makan, tingkat aktivitas tertinggi terjadi pada awal waktu pengamatan sekitar pukul 17.00 - 20.00 WIB kemudian mengalami penurunan aktivitas makan sampai tiga jam berikutnya. Pada strain VCRU terus mengalami penurunan dan kembali meningkat stabil dari pukul $02.00-11.00$ WIB kemudian turun drastis pada tiga jam berikutnya dan naik kembali pada pukul 14.00 - 17.00 WIB. Peningkatan dan penurunan aktivitas kecoak pada jam-jam tertentu dikarenakan perilaku hariannya terdiri dari dua fase yaitu dimulai pada saat terbenamnya matahari scotophase (periode gelap) dan berkurang dengan cepat setelah itu, kemudian kembali meningkat pada pagi menjelang photophase (periode terang) (Suliyat, 2009). Hasil penelitian yang telah dilakukan sesuai dengan penelitian Meswara et al. (2018), yang mengatakan bahwa berdasarkan aktivitas makannya kecoak lebih aktif dalam mencari dan makan pada malam hari dibandingkan siang hari. Kecoak pada umumnya menghindari cahaya dan pada siang hari bersembunyi di tempat yang gelap.

Kecoak Jerman merupakan hewan nokturnal tetapi pada penelitian kali ini terdapat peningkatan aktivitas makan yang terjadi pada pukul 08.00 11.00 WIB, hal ini mungkin karena umpan yang diberikan disukai oleh kecoak sehingga stimulasi fagostimulasi yang dimiliki kecoak tinggi. Kecoak pertama kali menggigit makanannya dan melepaskan cairan yang mengandung bahan kimia sebagai perangsang untuk makan. Hal ini kemudian membuat kecoak terstimulasi untuk makan. Kandungan nutrisi yang terdapat pada umpan menjadi faktor lain untuk merangsang reseptor makan. Temperatur juga memiliki pengaruh besar terhadap perilaku makan kecoak (Chapman, 2003). Suliyat (2009), menyatakan bahwa aktivitas pencarian makan dan minum berhubungan dengan fase aktivitas circadian, pada penelitian yang dilakukan aktivitas pencarian makan puncak pertama terjadi pada pukul $19.00-20.00$ WIB dan puncak kedua terjadi pukul 04.00 - 05.00 WIB.

Penelitian mengenai uji preferensi makan pada kecoak Jerman telah banyak dan terus dilakukan untuk mengetahui umpan apa yang paling disukai oleh kecoak Jerman. Pada studi kali ini melihat pemilihan umpan yang berbeda dari penelitian sebelumnya sangat penting dilakukan untuk mengetahui jenis fagostimulan apa yang sangat disukai oleh kecoak Jerman dan waktu aktivitas makan kecoak Jerman.

Berdasarkan ketiga parameter yang diamati berupa latensi, frekuensi, dan durasi, secara umum kecoak Jerman strain VCRU mendatangi semua jenis umpan yang diberikan, hal ini dikarenakan dalam kondisi kelaparan kecoak jantan memilih mencari sumber energi praktis yang sangat penting dalam menjaga kelangsungan hidupnya. Sehingga kecoak membutuhkan sumber energi utama berupa karbohidrat daripada lemak dan protein (Lauprasert, et al., 2006). Dalam penelitian kali ini gel gula lebih disukai dibandingkan ketiga umpan lainnya, karena kandungan gula yang terdapat pada gel gula meliputi beberapa jenis gula yang digabungkan.

Kandungan nutrisi pakan lain menjadi faktor utama dalam kebutuhan pakan hariannya. Pakan yang memiliki jumlah karbohidrat dan protein yang banyak biasanya menjadi pilihan utama (Az, et al., 2018). Ketertarikan kecoak Jerman terhadap pakan dipengaruhi dua faktor yaitu eksternal dan internal. Pengaruh faktor eksternal yaitu kandungan nutrisi pakan seperti gula (karbohidrat), protein, kadar air, dan aroma. Pengaruh faktor internal yaitu umur kecoak, jenis kelamin, dan tahap perkembangan (Lauprasert, et al., 2006). Besarnya kandungan air pada umpan dan tekstur umpan merupakan faktor lain yang penting. Umpan yang disukai kecoak 
adalah umpan yang tidak terlalu keras dan kering dimana faktor seperti kandungan air dibutuhkan (Suliyat, 2009).

\section{SIMPULAN DAN SARAN}

\section{Simpulan}

Berdasarkan penelitian yang telah dilakukan dapat disimpulkan bahwa kecoak jantan strain VCRU tertarik dan memilih semua umpan tetapi umpan gel dengan fagostimulan gula merupakan umpan yang lebih disukai. Puncak aktivitas makan strain VCRU terjadi antara pukul 17.00 - 20.00 WIB.

\section{Saran}

Saran yang dapat diberikan bagi peneliti selanjutnya yaitu perlu dilakukannya pengujian lanjutan untuk mengetahui jenis fagostimulan dalam penelitian ini yang memberikan respon metabolik yang paling baik bagi kecoak Jerman, karena pada penelitian kali ini hanya melihat respon kemosensorik.

\section{DAFTAR REFERENSI}

Ahmad, I., Fitri, L. L. \& Hariani, N., 2018. Pengembangan Formulasi Umpan Untuk Mengendalikan Kecoak Jerman Blattela germanica L. (Dictyoptera: Blattellidae) dan Lalat Rumah Musca domestica L. (Diptera: Muscidae) di Indonesia, Bandung: Institut Teknologi Bandung (Tidak dipublikasi).

Ahmad, I. \& Suliyat, 2011. Development of Fipronil Gel Bait Against German Cockcroaches, Blattella germanica (Dictyoptera: Blattellidae): Laboratory and Field Performance in Bandung, Indonesia. Journal of Entomology, 8(3): 288-294.

Ahmad, I., Waldbauer, G. P. \& Friedman, S., 1993. Maxillectomy Does not Disrupt SelfSelection by Larvae of Manduca sexta (Lepidoptera: Sphingidae). Ann. Entomol. Soc. Am, 86(4) : 458-463.

Amalia, H. \& Harahap, I. S., 2010. Preferensi Kecoa Amerika Periplaneta americana L. (Blattaria: Blattidae) terhadap Berbagai Kombinasi Umpan. Jurnal Entomologi Indonesia, VII(2) : 67-77.
Antarlina, S. S., 2009. Identifikasi Sifat Fisik dan KImia Buah-buahan Lokal Kalimantan. Buletin Plasma Nutfah, 2(15) : 80-90.

Arifah, F. G., Hestiningsih, R. \& Rahardian, R., 2016. Preferensi Keocak Amerika Priplaneta americana (L.) (Blattaria: Blattidae) terhadap Baiting Gel. Jurnal Kesehatan Masyarakat, 4(4).

Az, S. Z. N., Hariani, N. \& Trimurti, S., 2018. Studi Ketertarikan Kecoak Jerman (Blattella germanica L.) pada Karbohidrat dari Ampas Tahu dan Ampas Kelapa. Bioprospek, 13(1) : 12-18.

Chan, J. H. H. \& Martinez, C. A., 2007. Roach Bait Attractive To Many Species Of Roach And Useful In Their Rapid Control, United States: Patent Application Publication, Pub. No: US 2007/0014826 A1.

Chapman, R. E., 2003. Feeding Behavior. In: V. H. Resh \& T. R. CArde, eds. Encyclopedia of Insect. Florida: Academic Press, pp. 409414.

Dethier, V. G., 1954. Evolution of Feeding Preferences in Phytophagous Insect. Evolution, 8: 33-54.

Hadi, U. K. \& Sigit, S. H., 2006. Hama Permukiman Indonesia. 1st ed. Bogor: Institut Pertanian Bogor.

Lauprasert, P., Sitthicharoenchai, D. \& Pradatsusarasar, 2006. Food Preference and Feeding Behavior of The German Cockroach, Blattella germanica (Linnaeus). J. Sci, Res. Chula, 31(2).

Martin, P. \& Bateson, P., 1986. Measuring Behaviour: An Introductory Guide. New York: Cambridge University Press.

Martin, P. \& Bateson, P., 1993. Measuring Behaviour. 2nd ed. Cambridge: Cambridge University Press.

Mustikawati, D., Martini \& Hadi, M., 2016. Pengaruh Variasi Umpan Aroma Terhadap Jumlah Lalat yang Terperangkap Dalam Perangkap Warna Kuning (Studi di Kandang Sapi Dusun Tegalsari Desa Sidomukti Kecamatan Bandungan Kabupaten Semarang). Jurnal Kesehatan Masyarakat, 4(4) : 275-281.

Pol, J. C., Jimenez, S. I. \& Gries, G., 2017. New Food Baits for Trapping German Cockroachs, Blattella germanica (L.) (Dictyoptera: Blattellidae). Journal of Economic Entomology, 6(110) : 2518-2526.

Ratnasari, A., 2014. Efisiensi Larutan Antiseptik Ekstrak Daun Cengkeh (Syzygium 
aromatikum L.) Untuk Mortalitas Kecoa Sebagai Hama Pemukiman. ISSN 16937945, VI(12).

RI, D. G. D. K., 1981. Daftar Komposisi Bahan Makanan, Jakarta: Bhratara Karya Aksara.

Silverman, J. \& Bieman, D. N., 1993. Glucose Aversion in the German Cockroach, Blattella germanica. J. Insect Physiol, 39(11) : 925-933.

Steel, C. J. \& Torrie, J. H., 1995. Prinsip dan Prosedur Statistik. Jakarta: PT. Gramedia.

Suliyat, 2009. Umpan Gel Untuk Mengendalikan Kecoa Jerman, Blattella germanica (Dictyoptera: Balttellidae): Studi Laboratorium dan Lapangan, Bandung: Institut Teknologi Bandung.

Tang, S. B., Lee, J. C., Jung, J. K. \& Choi, M.-Y., 2017. Effect of Erythritol Formulation on The Mortality, Fecundity and Physiological Excreation in Drosophila suzukii. Journal of Insect Physiology, Issue 101 : 178-184.
Waldbauer, G. P. \& Friedman, S., 1991. SelfSelection of Optimal Diets By Insects. Ann. Rev. Entomol, Volume 36 : 46-63.

Wang, C., M, S. \& G, W. B., 2004. Behavioral and Physiological Resistance of The German Cockroach to Gel Bait (Dictyoptera: Blattellidae). J. Econ. Entomol, Issue 97 : 2067-2072.

Willis, M. A. \& Avondet, J. L., 2005. Odormodulated Orientation in Walking Male Cockroach, Periplaneta americana (L.) and The Effect of Odor Plumes of Different Structures. J. Exp. Biol, Volume 208 : 721735 .

Winarno, F. G., 2001. Hama Gudangdan Teknik Pemberantasannya. Bogor: M Brio Press. 